$$
\text { CONF- } 831174 \ldots 29
$$

\title{
TITLE: DISPROPORTIONATION AND POLYMERIZATION OF PLUTONIUM(IV) IN DILUTE AQUEOUS SOLUTIONS
}

I $\Lambda-U[R--83-32.95$

AUTHOR(S): T. W. Newton and V. L. Rundberg

DE84 003799

\author{
SUBMITTED TO: Materials Research Soclety \\ 1983 Annual Meet 1ng \\ November 1's-18, 1983 \\ Boston, MA 02177
}

\section{DISC'I.AIMFIR}

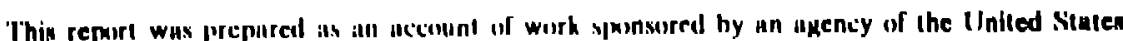

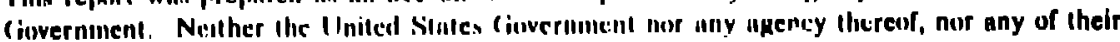
rmployees, mukes uny wurrunty, express or implicel, ur assumes iny legul liubility or responsi-

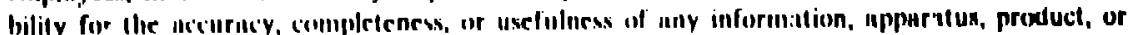
proness disclosed, or represents that its use would inot infringe privhtely owned riphts. Refer-

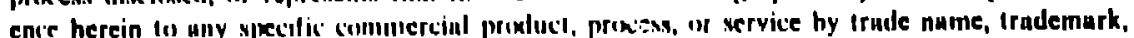

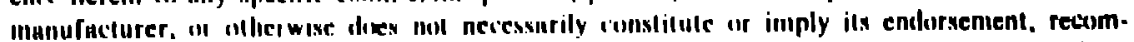

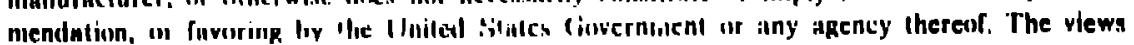

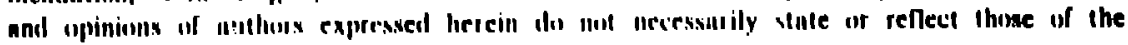

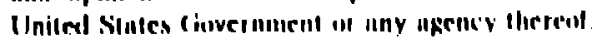

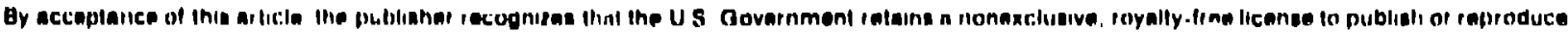

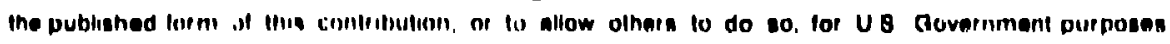




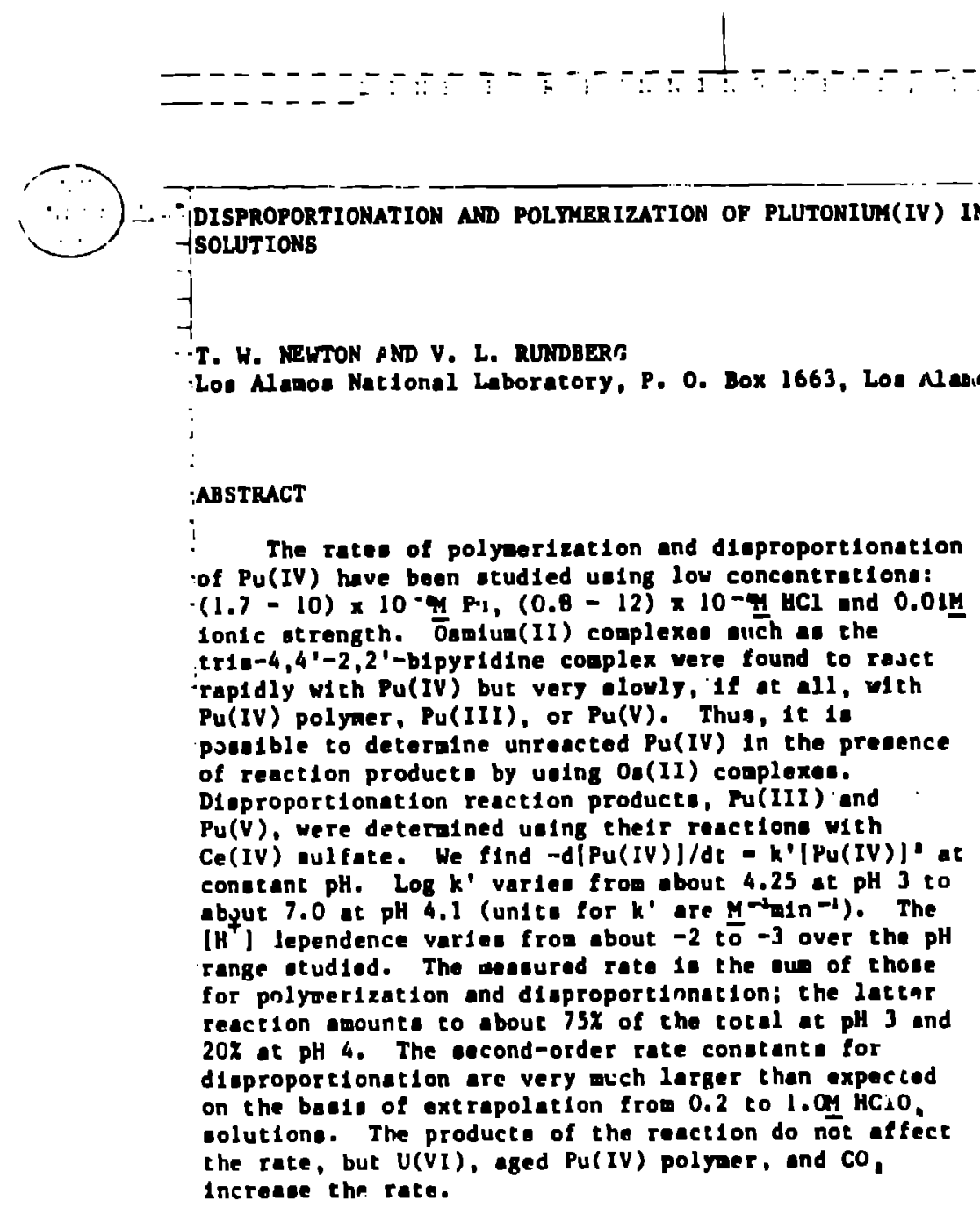

\section{INTRODUCTION}

The chemintry oI Pu(IV) in near-neutral solutione 1s roorly underatood, which meses it ver, diflicult to predict beliavior in groundwater, ouch as thoue prenent ai the proposed nuclnar water repository at Yucce Mountain in Nevada. In the abeence of otrongly complealng apecles, the principal reactione if Pu(IV) are hydrolyein, dieproportlonation, polyweriation, and finally, precipltation. The flrat etep in the hydrolyele of Pu(IV) becowe laportant ot falrly high acid concentratione and ant lafactory valuea for the flrat hydrislyale quolient are avallable [1]. The quollente for further hydrolyal. .re difflcult to deterolne becauce of the reactione sentioned abnve, but oprarent ly reasonablo eatlontes have been glven by Bara and Meamer 11). The ratea of dieproportionation of Pu(IV) In enjutions of unlt Ionir at length and $0.2 \leq\left|H^{\prime}\right| \leq 1$. UH have been reported by Rahideal $|2|$. Thrue renulte wy be extrapulated tō hlgher pH values and lower conceitrationa. Hovever, the ur ent imatee ere quite uncertaln and direct doterainationa vould he very uaeful. The extatence of polyaere of Pu(IV) 10 vell known, and Important propertiea have been revlewed by Cleveland [3]. More recently. rated ol polyaer foranclon iroe tairly concent caled colutiona have been

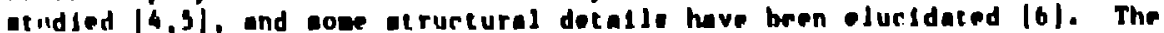
importance of the Pu(IV) polyerr In underatanding the behavior of plutonium 


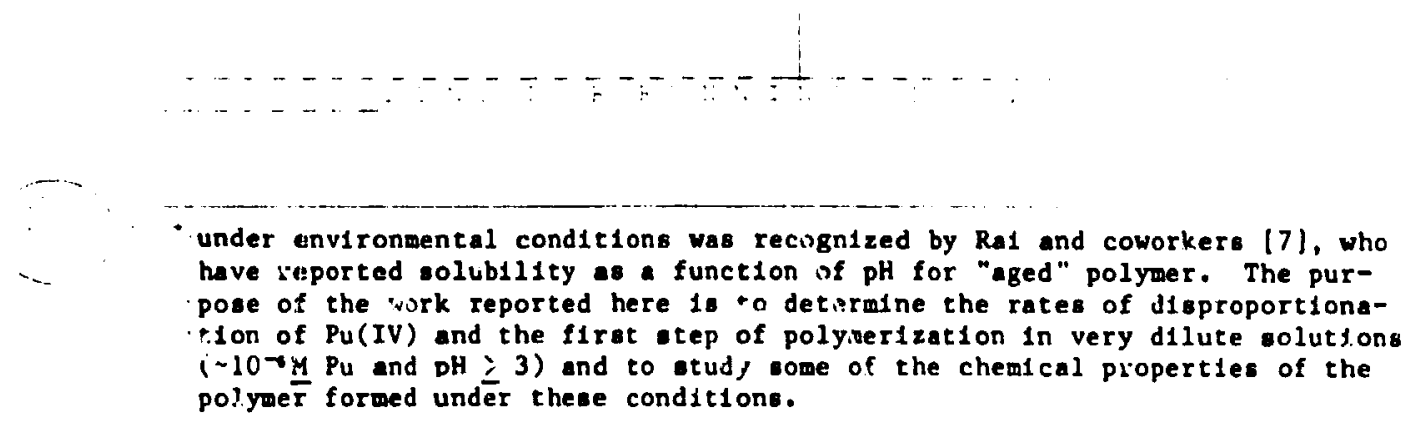

\section{M.:ERIALS AND METHODS}

\section{Reagente}

Pluton 1um(IV) etock solut1ons. Electroref1nid plutorilum-239 metal was dIssolved In 6M HCl. A portion of the Pu(III) for.ned was oxidized to Pu(VI) with fuming HCIO,. One equivalent of the Pu(VI) was added to two equivalents of $\mathrm{Pu}$ (III) to form $\mathrm{Pu}$ (IV) by the rapid reproportionation reaction. The final $H C l$ concentration was made $3 \mathrm{M}$ or greater to minimize disporportionation and alpha reduction. The amount of Pu(III) and/or Pu(VI! in the sock were estimated by absorption opectrophotometry at 600 and $8.30 \mathrm{~nm}$, respecsively.

Plutonlum (IV) polymer. Th1s material was prepared by diluting Pu(IV) otock olueion with weter to give a tinal mixture $0.008 \mathrm{~s}$. in Pu and $0.05 \mathrm{M}$ in HC1. This wixture was allowed to stand for about 1 week ind lonic impurities were removed by the use of atior exchange column (Dowex $50 \mathrm{x}-8$ ). The resulting green sol showed the visible absorption spectrum tharactiristic of the polymer $[6]$.

Onmium(II) complexes |81. The tria-bipyridine and trig-i, $4^{\prime}-d 1$ methyl2,2'-bipyrid'ne complexes were prepared by published methods (9). The formal potential o the dimethyl bipyridine complex was determined to be $-0.09 \mathrm{~V}$ less than that of the unuubatituted bipyridine complex, which is reported to be $0.885 \mathrm{~V}$. [10]. Thls was done uning potentlometric titration with cerle sulfate.

Other Reagenta. Ce(IV) from the G. F. Sulth Chemical Compan' was made up in $8 \mathrm{M} \mathrm{H}, \mathrm{SO}$. Hydroquinone was vacuum oublimed and diseolved 1 , distilled water. Pyridine wan repurifled by distillation. and lox by volume aolution was made by dilution with distlled water.

Annlvts cal Methodu

The plutonium concentration. encountered were too low for direct npectrophotometry, en indirect methoda baned on onmlum(II) complexen were drveloped. Theoe complexe react quite rapidly with monomerlo Pu(IV) but very - lowly with the product of dieproportionation or polymerization reacidons. For example, the apparent mecond order rate conotant tor che reduct 10 on of

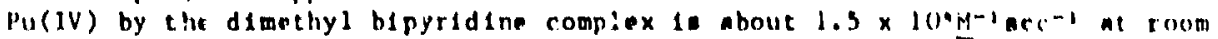
teepernture ald a 311 of 3 . The llpande on the oumlum are manntially nonlatile, and there ta no evidence that they can dimnociate and react with the plutenti:m. Becaume the onmfum(II) complexen have molat abactifivitien of

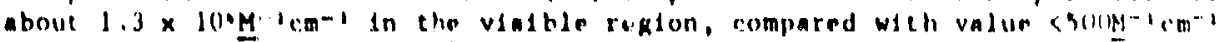

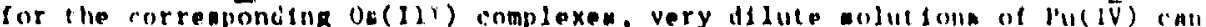
be malyend pectrophotometrleally.

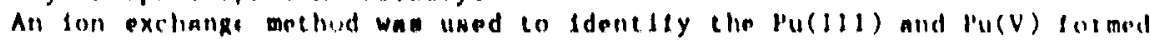
by diaproportionation. This wan dons by amane of amall fon axchanke columin rontalning zitconlum phonphate. an sukgented by cehmecker ot al. |ll|. III tida method, a ample in placed on the top of the columi and aluted witl.

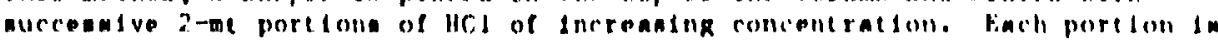

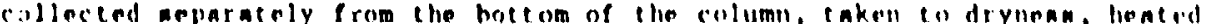

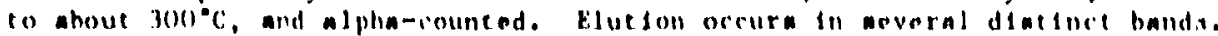




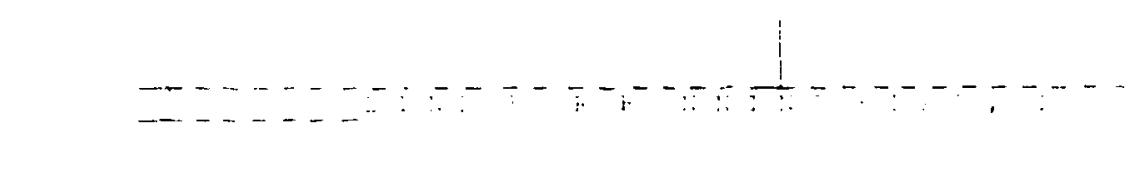

- Ine total reducing agent formed in the experimental oolutions was determined ueing Ce(IV) in dilute $\mathrm{H}_{2} \mathrm{SO}_{\text {. }}$. Th1s reagent reacts rapidly w4th Pu(III) and $\mathrm{Pu}(V)$ but only lowly, if at $\mathrm{all}$, with $\mathrm{Pu}(\mathrm{IV})$ and the $\mathrm{Pu}(\mathrm{IV})$ polymer. $A$ small excess of $\mathrm{Ce}$ (IV) in $8 \mathrm{M} \mathrm{H}, \mathrm{SO}$, was added to the solution and backt1trated spectrophotometrically at $320 \mathrm{~nm}$ wt otandardized Pu(III) solution. The acid in the Ce(IV) reagent was chosen to onke the final solution dbout $0.5 \mathrm{H}$ in $\mathrm{H}_{\mathrm{a}} \mathrm{SO}$.

Procedure

Solutions for the kinetic experimente were prepared by adding omall weasured volumes of $\mathrm{Pu}$ (IV) in $3 \mathrm{M} \mathrm{HCl}$ to much lerger volumes (typically 60 m 2 ) of $0.01 \mathrm{M} \mathrm{HCl}$ containing enough pyridinc to give the desired pli. Unreacted Pu(IV) Was determined as a function of tiwe by adding $0_{s}$ (II) complex to reouce the $\mathrm{Pu}$ (IV) and quench the reaction. The 0 (III) complex that forwed, and hence, the Pu(IV) present at the time of quenching, was determines from the increase in absorlance after adding excess hyjoquinone, which rapldly reduces the $0 \mathrm{~s}$ (III). For runs with $\mathrm{ph}$ values greater than -3.5 , it was necessary to quench the reaction with 0.3 meq of HCl fust befor adding the Os(II). This exces acid was neutrallzed with 0.3 meq of $\mathrm{NH}, \mathrm{OH}$ before adding the hydroquinone. The reaction vessels were epecial 10-cm absorption cells equipped with magnetically driven Teflon-covered otir bars. Abanrbance was determined at $23^{\circ} 1^{\circ} \mathrm{C}$ by using a Cary Model i7n epectrophotometer. After esoentially all the monomeric $\mathrm{Pu}(\mathrm{IV})$ had reacted, the total reducing ager, that formed was deterwined by using Ce(IV) as deccribed alove.

Extrapolation of Diaproportionation Data

Rabideau et al. [2b] have given a two-term rate law for the disproport1onation of Pu(IV) at $25^{\circ} \mathrm{C}$ and $I-1.0 \mathrm{M}$. We have exirapolated the two rate constante to $1=0.01 \mathrm{M}$ by uoing an extented form of the Debye-kulckel Equation with parameters oulabile for oxiJation-reduction reactions $|12|$. The reauling rate law is

$-c[P u(I V)] / d t-2\left(7.1 \times 10^{-5}\left[\left.\mathrm{H}^{+}\right|^{-3}+5.3 \times 10^{-5}\left[\mathrm{H}^{+}\right)^{-4}\right)\left(\mathrm{Pu}^{4+}\right)^{2} \mathrm{M}^{-1} \operatorname{cec}^{-1}\right.$.

However, $\left|\mathrm{Pu}_{\mathrm{U}}+\right|-|\mathrm{Pu}(\mathrm{IV})|\left(1+\mathrm{EK}\left|\mathrm{H}^{+}\right|^{-1}\right)-1$, where the $\mathrm{K}$, are the hydrolyrit

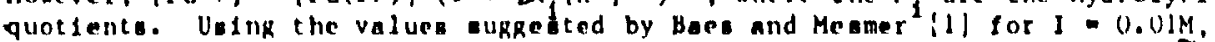
we find $\log k_{1}--0.76,-2.72,-3.82,-10.02$, and -15.42 tor $1-1$ to 5 , renpectivelv. These consideration lead to valuen for the anparent ancond-

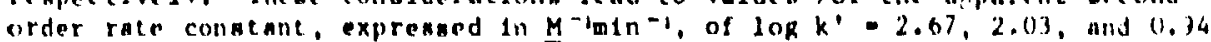
at pll - 3.0, 3.5, and 4.0, reapectively. The relative concentrationa of thr

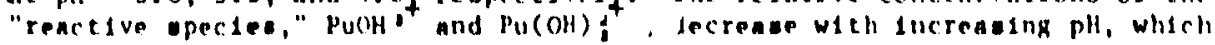
caunes the calculaced decrenen in rate. Tile producte of diepropo:tionation at pll $>3$ arr predominant ly pu(111) and Pu(V) becmune the extenalve hydrolyal of pu(IV) caunce the equilibrium in the reaction

$$
P_{u}(111)+P_{u}(V I)-P u(I V)+P_{u}(V)
$$

to lle far to the right.

MEsILTS

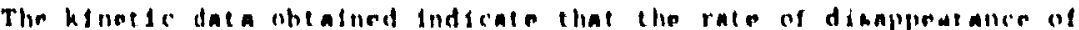
momemerle lu(IV) (that which react rapldly wlth ou(II) complexen) la pre

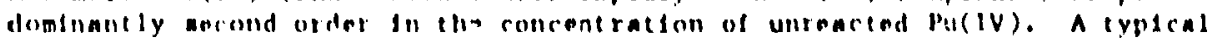
plot of concontention vin tlas in bhown in Fig. 1. 


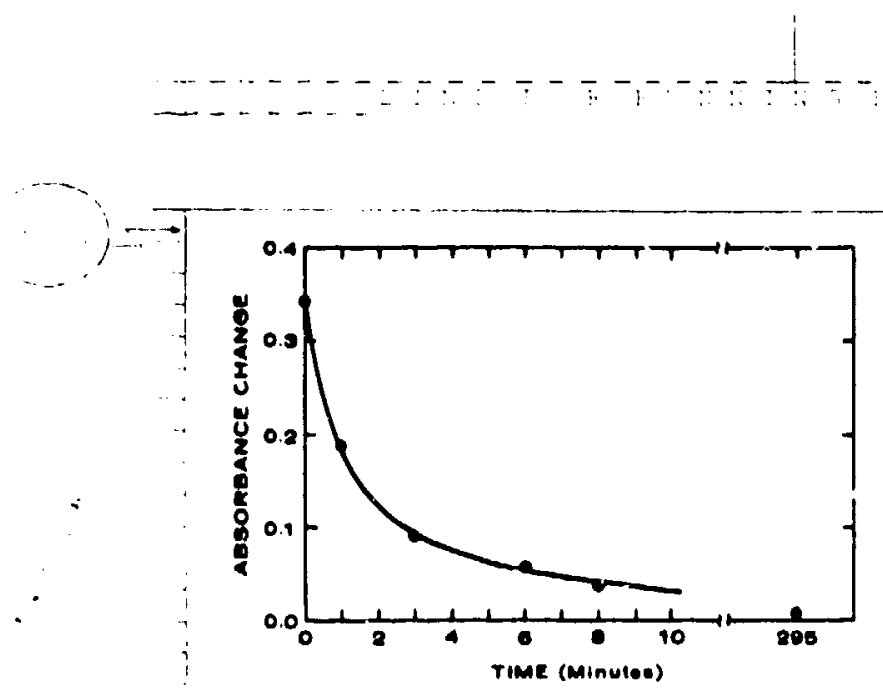

FIG. 1. Absorbance change ve time. Sol1d curve for second-order rate law.

Apparent econd-order rate constants vere determined as a function of $\mathrm{pH}$ in the range from 2.9 to 4.1 . A plot of the logarithm of the rate conctant. expreased in $\mathrm{M}^{-1} \mathrm{~m} 1 \mathrm{n}^{-1}$, is shown In F1g. 2. The rate depends itrongly on the $\mathrm{pH}$; the lope of the curve increases trom -1.9 at $\mathrm{Ph} 3$ to $\sim 2.9$ at $\mathrm{pH} 4$. In most of the runs, the initial Pu(IV) concentration was in the range $(1.7$ to 2.0$) \times 10^{-} \mathrm{M}$, but in ame runs, the concentrations were $3 \times 10^{-} \mathrm{M}$ and $1.0 \times 10^{-1} \mathrm{M}$. The effect of varying initial Pu(IV) concentration was within the experimental error in the determinat ons.

The products of the reaction had no significant fiect on the rate. A solution containing $4.2 \times 10^{-} \mathrm{M}$ Fu(IV) at $\mathrm{pH} 4.3$ was allowed to etand unt11 the monomeric Pu(IV) hed diappeared, principaliy by polymerization. More Pu(IV) was added and 1 to rate of diappearance was determined as before. The rates in these experiment agreed within $5 x$ with those of companson ruils without product but di the same pH.

Aged polymer, however, caused a igniflcant increase in the rate of disappearance of Pu(IV). The polywer was prepared as descrlbed above, aged at room temperature for 10 monthe and puilfied by 1 on exchange before use. Rates of diseppearance of $\mathrm{Pu}$ (IV) in solutiona containing $7.8 \times 10^{-} \mathrm{M}$ of this polywer were compared with those from solutions with the same pll blit without polymes. The rate in the prenence of polymer wan increased by factor of $6.2 \pm$ 0.5 .

Toth et al. (5) reported that $U(V I)$ reduced the rate of polymurization in their experiments at $50^{\circ} \mathrm{C}$. The rate wan decroneed by about $30 \%$ by $0.5 \mathrm{M}$ U(VI) in a mution 0.05M in plutondum and $0.11 \mathrm{M}$ in HÑO . find that the effect 1 a much different rt lower temperatures and concentrationa. Experimente were done at $23.5+0.5^{\circ} \mathrm{C}$ by Uoinp $1.8 \times 10^{-1 M} \bar{P}_{u}$ (IV) and 3.3 $x l(1-1 M U(V I)$ at pll valuen of 1.0 alid 3.3. In both exper1mente, the oberved mecond-order rate conntants were about $40 \mathrm{z}$ largar than thome expected without U(VI), Thus, at lower tomperature and concentrationa the effect appeara to be Intaner por $M$ of U(VI) and of opponite 1 in.

Ancallow both polymerisation and dimpreportionation leactiome were oxpocted, we uned the

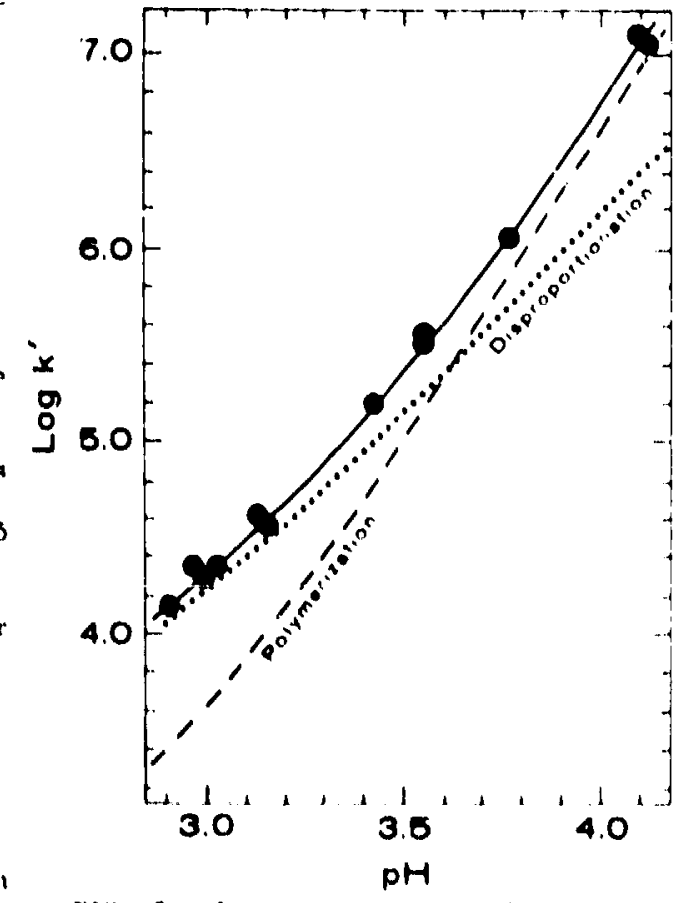

Hic. 2. Inp apparent accond-order rate conotunt vo ph. 


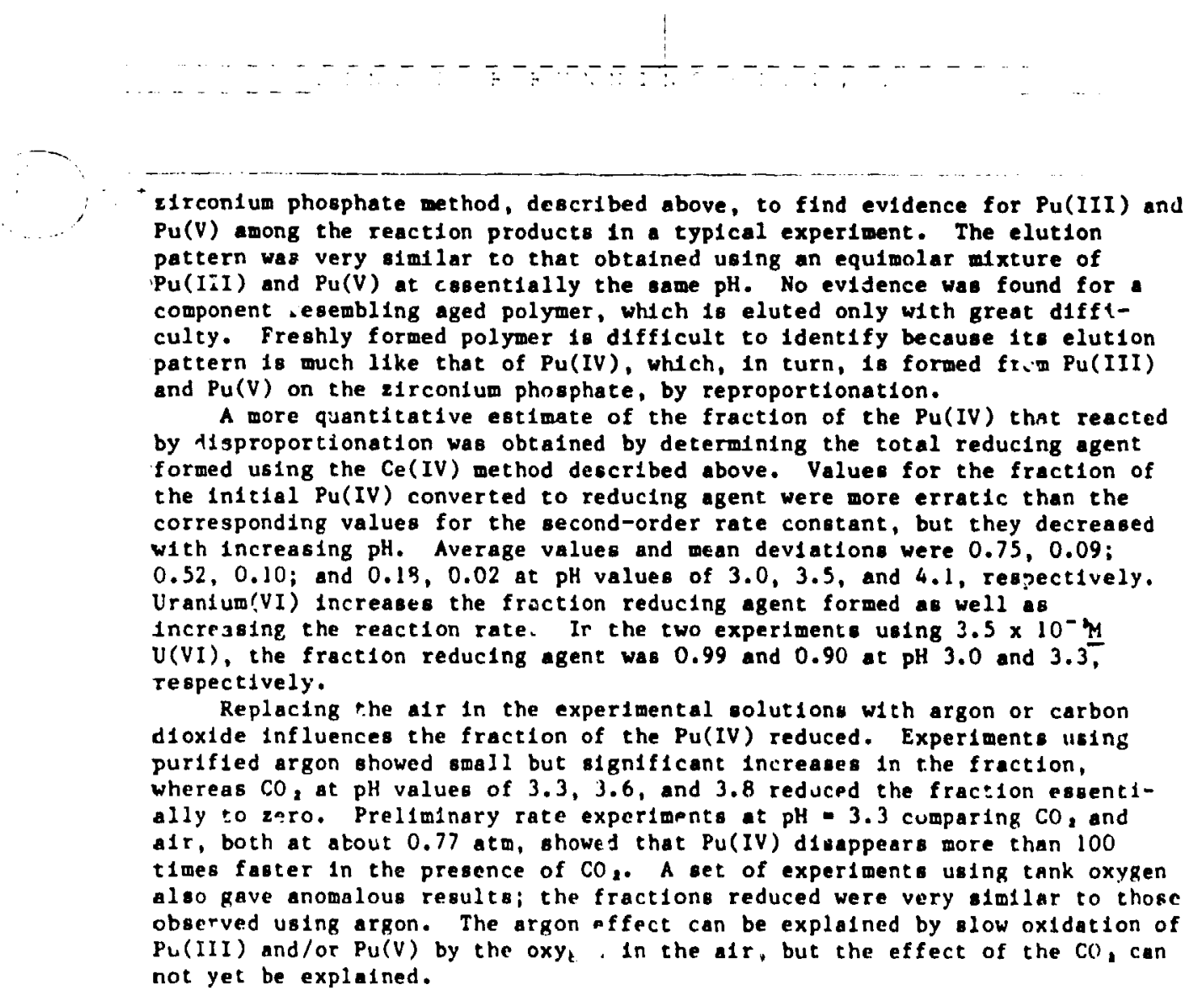

DISCUSSION

The data Indicate that Pu(IV) disappear by dieproportionation and by an additional procese. Although direce culdence for polymerization under our experimental conditions 1: lacking, the fact that polymer readily forms at higher concentrationa makes it highly likely that the firat etage of polymersization in the additlor.d process. The values fuund for the fraction of the InItal Pu(IV) converted to roducing agent were uned to entimale the rates of the individual procesaea, diaproportionation and poljmerization, as n function of pH (F1g. 2). Dioproportionation 1s the predominant reaction for low cincentrationa of PU(IV) and pH 3, but polyweriention dominates at pH gresier than nbout 3.3 .

The determination of the rate constant involved the chemical analyad. of meprate vary dilute olut lone an a function of time and, therefore, wan

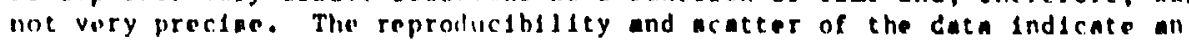
uncortanty in the lnparlllim of the ouarall rate conctante of about $\pm 0,0 \%$.

A reliable extrapolation of the rate dain to $\mathrm{pH}$ velues conalderñbly

hipher than the experimental range wlll requirn rate lawe in terma of apecien

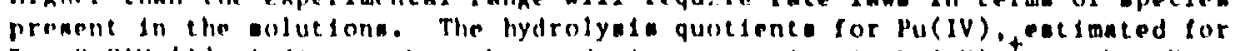
1 - $0.01 \mathrm{M} \mid 1)$, Indicate that the predominant upecles 1s Pu(OH), in the $\mathrm{nH}$ range from 3.1 to 4.2 . The rate law for polymerienten en terme of this apriten 1n

$$
\left.\left.d \mid p u) y\left|/ d z=\left(k_{1} \mid H^{+}\right)^{-1}+k_{2}\right| H^{+}\right)^{-2}+k_{3}\left(H^{+}\right)^{-4}\right)\left|P u(O H)_{3}^{+}\right|^{2} \text {. }
$$

where threr rate comatante are approxlmately $12.9 \mathrm{~min} 1.6 .4 \times 10^{-} \mathrm{M}$

m $1 n^{-1}$ and $1.1 \times 10^{-1} M^{1}$ me $1 n^{-1}$, renpectlvely. Thene race conacantin thow the

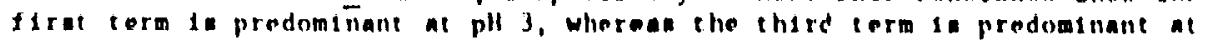




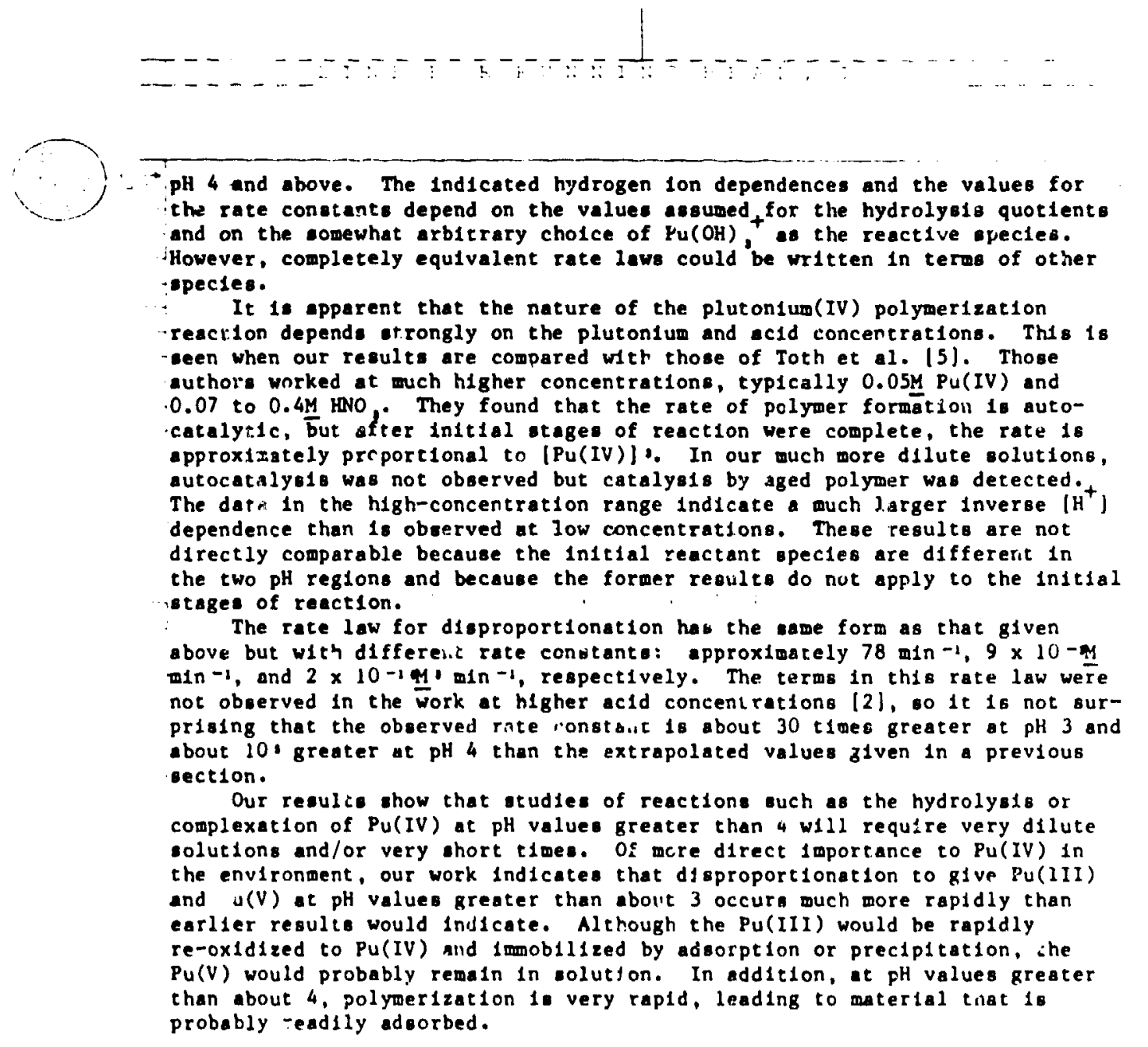

\section{ACKNOWLEDGEMENTS}

Th1. work was supported by the US Department of Energy, Office of Basic Energy Science and the Nevada Nucleat Waste Storage Investigations. In addition, we thank Professor Henry Taube for suggesting the use of osmium complexes and Profesuor David Klanaen for help in thelr wythemes.

REFERENCES

1. C. F. Baeb and R. E. Meamer, The Hydroljele of Catione (John Wiley and Sone. New York, 1976), pp. 187 .

2. (a) S. W. Rabldeau, J. Amer. Chew. Soc. 75, 798-801 (1953).

(b) S. W. Rabidenu el 1 .. Proc. Zno UN Int. Conf. on Peaccful Unes of At. Energy, Geneva, $28,361-: 32$ (1 58$)$.

3. J. M. Cleveland, The Cliemlatry of Plutonlum (Gordon ard Breach Sclence Pibliahera, New York, 1970), pp. 83-89.

4. J, T. Dell, D. A. Contanzo, and R. E. Bigkere, 2 . Inork. Nuc1. Chem. 35. 6: $3-628(1973)$.

3. L. M. Toth, H. A. Trledmail, and M. M. Ouborne, J. Inorg. Nurd. Chem. 43 , $2929-2934(1981)$. 
6. - M. H. Lloyd and R. G. Haire, Radioch1m. Acta 25, 139-148 (1978).

7. D. Ral and. L. Swanson, NL i. Technol. 54, 107-112 (1981).

8. H. Tube, Stir ord University, suggested uge of $0_{s}$ complexes, personal communication.

9. R. H. Fab1an, D. M. Klassen, and R. W. Sonntag, Inorg. Chem. 19,1977 (1980).

10. D. A. Buckingham, F. P. Dwyer, and A. M. Sargeson, "Osmium(III)Osint um(II) Electrode Potent1als," Inorg. Chem. 5, 1243 (1966).

11. H. Gehmecker, M. Lerch, R, Heimann, A. K. Kaffrell, A. Lewening, N. Trautmann, and G. Heirmann, Institut für Rernchemle der Universit lat Mainz, Germany, personal communication.

12. T. W. Newton, ERDA Critical Review Series, TID-26506 (1975) p. 68. 